\title{
Creativity-enhancing work environments: Eventisation through an inspiring work atmosphere in temporary proximity
}

\section{Kreativitätsfördernde Arbeitsorte: Eventisierung durch eine inspirierende Arbeitsatmosphäre und temporäre Nähe}

https://doi.org/10.2478/rara-2019-0039

Eingegangen: 8 Oktober 2018; Angenommen: 23 Mai 2019

\begin{abstract}
The objective of this paper is to understand how work processes and the quality of physical places support creative knowledge generation. The creation of knowledge is linked to both social space and physical place, and is influenced by steady socio-spatial dynamics. In workplaces, the space-time dynamics of knowledge creation coincide with the physical characteristics of place. On the basis of qualitative interviews with Design thinking workshop facilitators, as well as participants, the influence of three types of creative support (psychosocial, inspirational and functional) is linked to the elements of place, people and process in this specific innovation method. This paper discusses in which ways place, people and process contribute to creating a creativity-enhancing workspace and inspiring atmosphere in temporary spatial proximity. Eventisation of the innovation process, and interaction in temporary spatial proximity, are important prerequisites for keeping knowledge creation exciting.
\end{abstract}

Keywords: Creativity-enhancing environments, temporary spatial proximity, knowledge creation, Design thinking, eventisation

Kurzfassung: Ziel dieses Beitrags ist es, den Zusammenhang zwischen Arbeitsprozessen, der Qualität der physischen Arbeitsumgebungen und der Unterstützung von Kreativität bei der Schaffung neuen Wissens zu analysieren. Die Generierung neuen Wissens wird stets sowohl durch soziale Prozesse als auch spezifische, physische Orte beeinflusst. Arbeitsplätze vereinen die sozialen Dynamiken von Wissensgenerierung mit den räumlichen Charakteristiken des Ortes. Mithilfe von qualitativen Interviews mit Design thinking-Workshopteilnehmern und -anbietern wird aufgezeigt, inwiefern sich unterschiedliche Formen der Unterstützung von kreativen Prozessen (psychosoziale, inspirierende und funktionale Unterstützung) mit den unterschiedlichen Elementen dieser Innovationsmethode - Ort, Mensch und Prozess - verbunden sind. Der Beitrag diskutiert, inwiefern das Zusammenspiel von place, people und process dazu beiträgt, eine kreativitätsfördernde Arbeitsumgebung sowie eine stimulierende Atmosphäre in temporärer Nähe zu schaffen. Die „Eventisierung“ des Innovationsprozesses sowie die Interaktion in temporärer räumlicher Nähe sind hierbei wichtige Voraussetzungen, um den Prozess der Wissensgenerierung spannend zu halten.

Schlüsselwörter: Kreativitätsfördernde Arbeitsumgebung, temporäre räumliche Nähe, Wissensgenerierung, Design thinking, Eventisierung

\footnotetext{
${ }^{*}$ Corresponding author: Madeleine Wagner, Universität Heidelberg, Geographisches Institut, Berliner Straße 48, 69120 Heidelberg, Deutschland, E-mail: madeleine.wagner@uni-heidelberg.de

Prof. Dr. Anna Growe, Universität Heidelberg, Geographisches Institut, Berliner Straße 48, 69120 Heidelberg, Deutschland
} 


\section{Introduction}

In these times of increasing globalisation and digitalisation, new challenges arise for knowledge-based activities and their spatial embeddedness. Two main strands of research can be identified in this context. The first strand deals with social processes, focusing on actors, their networks, and processes dealing with knowledge creation and knowledge exchange in the respective networks (Bathelt/Malmberg/Maskell 2004; Asheim/Coenen/Vang 2007; Cohendet/Grandadam/ Simon et al. 2014; Grabher/lbert 2017; Spigel 2017). The second strand deals with new spatial configurations resulting from globalisation and digitalisation processes, and the need to create new knowledge in economic processes (Nonaka/Toyama/Nagata 2000; Amin 2004; Castells 2010). A distinctive focus is placed on new workplaces (Merkel 2015; Schmidt/Brinks 2017; Growe 2018a), and the combination of different ways of interacting (Maskell/Bathelt/Malmberg 2006; Bathelt/Turi 2011; Schüßler/Grabher/Müller-Seitz 2015).

Recent studies, however, have tried to combine the research strands dealing with social and spatial configurations. Such attempts can be differentiated into two main perspectives. The first perspective is mainly adopted in economic geography (Bathelt/Malmberg/ Maskell 2004; Hess/Yeung 2006; Glückler 2007), as well as in management and organisational studies (PerrySmith/Shalley 2003; Waseem/Biggemann/Garry 2018). It promotes a focus on the spatial, but also the temporal, embeddedness of actors, their networks and processes, and has driven attention towards temporary spatial configurations (Torre/Rallet 2005; Maskell/Bathelt/ Malmberg 2006; Robertsson/Marjavaara 2015; Flögel/ Zademach 2017; Grabher/Melchior/Schiemer et al. 2018; Growe 2018a; Growe 2018b). A distinctive focus is placed on temporary clusters (Maskell/Bathelt/Malmberg 2006; Bathelt/Schuldt 2008; Rychen/Zimmermann 2008; Zhu/ Chen/Lian 2018), project work (Grabher 2002; Grabher/ Melchio/Schiemer et al. 2018) and temporary face-toface interaction in everyday work processes (Storper/ Venables 2004; Asheim/Coenen/Vang 2007). This first perspective is widely discussed in geography; however, it still focuses strongly on social interactions.

The second perspective is discussed less in geography. This research deals with the interrelation of physical places; for example, office layouts or building design, and the work processes carried out in the respective physical settings. The main question discussed here is that of how physical environments influence and enhance creativity. This perspective is mainly rooted in architecture (Toker/Gray 2008; Martens 2011; Lee 2016), design (Thoring/Desmet/Badke-Schaub 2018), psychology (McCoy/Evans 2002; Shibata/Suzuki 2004; McCoy 2005; Toker/Gray 2008; Magadley/ Birdi 2009; Steidle/Werth 2013; Hoff/Öberg 2015) and management research (Ceylan/Dul/Aytac 2008; Dul/ Ceylan 2011; Dul/Ceylan/Jaspers 2011; Oksanen/Ståhle 2013; Dul/Ceylan 2014; Sihvonen/Cnossen 2015), although it is also discussed in other disciplines, for example, in sociology (Vithayathawornwong/Danko/ Tolbert 2003) and work science (Haner 2005).

The latter perspective has also gained the attention of the wider public. Recent activities, for example creating architecturally ambitious headquarters or installing creative rooms within businesses, carried out by globally active enterprises, such as Apple Inc. or Deutsche Bank, have been reported in daily and weekly newspapers and in so-called coffee table books (Uebernickel/ Brenner/Naef et al. 2015). Picking up on the influence of architecture and the physical environment on human activities, the questions discussed in this paper can be understood as a subtopic of the complex interrelations between humans and places.

The aim of this paper is to combine the two perspectives dealing with (i) the spatio-temporal embeddedness of social processes, and (ii) the assumption that a distinctive physical environment can influence social processes in the context of knowledge generation in work processes. To do so, the innovation method of design thinking is focused upon. This method utilises user interaction in temporary spatial co-presence, and breaks up habitual thinking to combine feasibility, viability and user interest (Sauvonnet/Blatt 2015; Uebernickel/Brenner/Naef et al. 2015). The elements of people, process and place play a role here (Plattner/ Meinel/Leifer 2018).

In this paper, using the example of design-thinking workshops, an analysis is provided of the extent to which the quality of place is a supporting condition for triggering knowledge creation and exchange processes beyond the (in geography) much-studied elements of people and process. Here, quality of place refers to material elements (how is the place designed, and what material elements can be found there?), as well as social aspects (who is acting in the places, and what processes are being carried out?). This understanding is based on the definition of quality of place by Gertler and Levitte (2005: 505), who argue that including "not only the usual list of physical recreational and cultural amenities [what is there], but also social characteristics such as low 'barriers to entry' and the presence of a critical mass of 
creative people [who is there] is vital to ensure that local communities are open to inflows of knowledge and talent [what is going on]".

The paper is structured as follows. In the next section, interlinkages between social space and physical place are examined, and we introduce how physical places can support creativity and social processes in terms of knowledge creation, explain the meaning of temporality and places, and the method of design thinking as a supporting approach to combine social space and physical place. The third section provides an analytical framework of three supporting aspects, combined with the three main elements of the design-thinking approach. This analytical framework is used to explain the sociospatial dynamics in the process of knowledge creation in innovation processes. The methodology and data section follows. Then, in Section 5, the empirical results of the interviews are provided. This section interprets these results in the context of the analytical framework presented in Section 3. The discussion part of the paper summarises the findings concerning the interlinkages between social space and physical place in the creative processes of knowledge generation.

\section{Interlinking social spaces and physical places}

\subsection{Creativity-enhancing support through physical places}

Following Rutten (2017), the creation of knowledge is linked to both social space and physical place, and is influenced by steady socio-spatial dynamics. Knowledge is often referred to as local because it is always related to individuals, and these are "spatially sticky to the place where they live and work" (Rutten 2017: 162). However, knowledge generation and transmission is not locally limited because it occurs through social interactions, or 'conversations', that are not tied to special places. Conversations are described as "social spaces in which individuals from multiple organisations engage and contribute to a body of knowledge that firms tap into to fuel their innovation process" (Rutten 2017: 174). Thus, the concepts of 'physical place' and 'social space' are inextricably interwoven, influencing each other. Work environments and, therefore, the associated quality of place (Florida 2006) of the workplace, have an impact on knowledge creation.
In workplaces, the space-time dynamics of knowledge creation coincide with the physical characteristics of place. Therefore, microgeographies of knowledge creation imply that it is not so much on the urban or regional scales that knowledge creation happens, but on the smaller scale of micro-locations, such as offices, conference venues, studios, hotels and cafés, which can be used as workplaces in creative industries (Rutten/Boekema 2012; Grandadam/Cohendet/Simon 2013; Flögel/Zademach 2017). How exactly the social processes of knowledge creation are connected to such places is still debatable, however (Rutten 2017). In this context, Flögel and Zademach (2017: 303) argue for "studying [...] actual sites of knowledge creation, which implies analysing the micro-geographical scale".

Coming mainly from an architectural and design or management background, research studying actual sites of knowledge creation focuses on how workspaces and offices in firms (understood mainly as the premises of the firm) should be laid out (Haner 2005; Lewis/Moultrie 2005; Allen/Henn 2007; Martens 2011; Dul/Ceylan 2014; Hoff/Öberg 2015). In this regard, the studies deal with a variety of physical aspects, such as plants and light (Dul/Ceylan 2014), furniture (Hoff/Öberg 2015), office floor layouts (Allen/Henn 2007) or the availability of fun and playful elements (Lewis/Moultrie 2005), linking these to creative work processes, while creativity is "the ability to produce work that is both novel (i.e. original, unexpected) and appropriate (i.e. concerning tasks constraints)" (Suwala 2014: 48)

Studies dealing with creative processes and the physical environment argue that varying and flexible workplaces (Haner 2005; Allen/Henn 2007; Growe/ Mager 2018) are important in providing a feeling of security (Martens 2011) and in encouraging curiosity (Lewis/Moultrie 2005). Recommendations about providing varying and flexible workplaces mainly cover the availability of different workplaces that either enable interaction (Haner 2005; Lee 2016) or provide private spaces to promote 'flow' (Csikszentmihalyi 2010) in creative work. Breaking these requirements down to the physical environment of workplaces, many studies deal with the varying opportunities of individual and team workplaces that can be characterised through different nuances of flexibility (for an overview, see Uebernickel/ Brenner/Naef et al. 2015).

The aim of this paper is to think together physical places, interacting actors and the design of the creative process itself to analyse how creativity can be supported. A starting point for differentiating creativity-supporting factors are the three dimensions by Hoff and Öberg 
Table 1: Three dimensions of creativity-enhancing support through physical places

\begin{tabular}{|c|c|c|}
\hline $\begin{array}{l}\text { Psychosocial support } \\
\text { (increase well-being, decrease stress } \\
\text { and social barriers) }\end{array}$ & $\begin{array}{l}\text { Functional support } \\
\text { (increase job performance, } \\
\text { decrease distraction) }\end{array}$ & $\begin{array}{l}\text { Inspirational support } \\
\text { (increase creativity and quality) }\end{array}$ \\
\hline Private space & Ergonomic tools and furniture & Creative space \\
\hline Customised space & Lighting & Inspiring places - architectural planning \\
\hline Window view & Distraction-free space & Inspiring places - interior design \\
\hline Stress management spaces & Adequate space & Spaces for brainstorming \\
\hline $\begin{array}{l}\text { Spaces for connection and communicating } \\
\text { ideas } \\
\text { Informal social spaces } \\
\text { Non-hierarchical spaces }\end{array}$ & Adjustable spaces and furniture & \\
\hline
\end{tabular}

Source: Authors' table based on Höff/Öberg (2015)

(2015). Hoff and Öberg (2015) argue that the physical work environment influences both the individuals and the creative process itself, in different ways. Thus, the output generated - the innovation - is also influenced by the physical work environment through creativitysupporting factors. Supportive factors in the physical work environment include psychosocial aspects, as well as functional aspects and inspirational aspects (see Table 1).

\subsection{Eventisation through temporary use of physical places}

As the creation of knowledge is linked to both social space and physical place (Rutten 2017), the temporary use of places, as a result of changes between places, can lead to changing creativity-enhancing support. The temporary use of places thus far has mainly been discussed in the context of 'temporary spatial proximity'. This term is used to describe temporary measures for establishing and maintaining interaction between working partners in processes of knowledge generation and knowledge exchange. Studies concerning temporary spatial proximity mainly focus on specific types of temporary clusters, such as trade fairs, conferences or exhibitions (Bathelt/Schuldt 2008; Bathelt/Henn 2014; Henn/Bathelt 2015), or on the role that temporary spatial proximity plays in learning processes (Grabher 2004; Bathelt/Gibson 2015; Müller/Stewart 2016). Rychen and Zimmermann (2008: 772) introduced two types of temporary spatial proximity: (i) temporary clusters and (ii) 'moving'. They conceptualised temporary clusters as being specific settings that enable the seeking and finding of new partners, whereas 'moving' refers to bilateral or multilateral relations between companies that are already partners (see Growe 2018a).
While it is possible to fundamentally differentiate between temporary clusters and temporary meetings in everyday working processes with regard to the conceptualisation of power relations between actors (Grabher 2002), buzz (Maskell/Bathelt/Malmberg 2006; Growe 2018a) and knowledge-generating mechanisms (Henn/Bathelt 2015), one aspect remains important for both settings. Temporary limited use of spatial settings enables actors to meet for a certain, predetermined period at a specific location, usually away from the places in which the participants live and work. This results in an easier way of thinking and acting outside of routine, and facilitates, for instance, meeting new stakeholders (Bathelt/Schuldt 2010), communicating more openly (Bathelt/Henn 2014; Bathelt/Gibson 2015) and generating new ideas.

The dynamic interrelation of social spaces and physical places, which occurs temporarily, also favours a certain kind of eventisation. In the literature, eventisation is mainly rooted in urban system research (Betz/Hitzler/ Pfadenhauer 2011; Smith 2015), ethnography and education (Hitzler/Kirchner/Pahl 2013; Perlick 2014), sociology (Betz 2018) and sports (Klein 2016). All proceedings described in the literature, such as music festivals, the Olympic Games, horticulture exhibitions, international building exhibitions or world youth days (Betz/Hitzler/Pfadenhauer 2011), have in common that the aspect of temporality in particular, the special equipment and the atmosphere of the physical place play a crucial role in creating an event (Pallasmaa 2014).

These observations can also be transferred to innovation processes and work science. In applying the innovation method design thinking, an eventisation of the work process can be observed. With regard to six criteria of events, the workshops themselves can be understood as events. According to Lange, Power and Suwala 
(2014: 188), events are characterized by "(a) pooling of diverse actors in one place, (b) bounded temporality (from hours to days), (c) spontaneous opportunities for direct social interaction, (d) symbolic (dramaturgical, ceremonial, performative) constituent parts, (e) incidents for information exchange and collective sense-making and (f) reservoirs for social resources and manifold utilization". These criteria also support attentiveness in work processes.

On one hand, the aspect of emotionalisation plays a crucial role in eventisation (Burzan 2017). In the definition according to Lange, Power and Suwala (2014: 188) emotionalisation is described as a symbolic constituent part of the working process and results in participants thinking divergently, like for example with special rituals in the workplace. The second criterion for eventisation is that the participants can link the new experiences to their everyday lives and work processes (Gebhardt/ Hitzler/Pfadenhauer 2000; Betz/Hitzler/Pfadenhauer 2011; Hitzler 2011). We argue that, aside from the social and physical aspects, temporality is also indispensable for the eventisation of processes (temporal socio-spatial dynamics). Through the temporally limited interplay of the physical place (the physical work environment) and the social space (the interaction of the creative workers in co-presence), a special working atmosphere is created. The temporary interaction of workers in physical workplaces leads to the creation of a certain event character, which in turn promotes creativity in innovation and knowledge generation processes (Lange/Power/ Suwala 2014; Henn/Bathelt 2015; Schüßler/Grabher/ Müller-Seitz 2015). Habitual thinking structures and behaviours fade into the background, and the atmosphere is affected by eventisation through the interplay of social, physical and temporal aspects.

Through temporality between social spaces and physical places, therefore, eventisation can support the openness and inspiration necessary to support the illumination phase in the creative process, in which a 'happy idea' occurs (Lubart 2001; Wallas 2014; Amabile/ Pratt 2016). With regard to design thinking, the element of temporary limited use of specific, physical places affected by eventisation is important, as the use of specific places outside of daily routines is part of the method for supporting the development of creative solutions.

\subsection{Combining social interaction and physical places in the design-thinking approach}

Design thinking has been developed as a management approach, describing "the way designers think: the mental processes they use to design objects, services or systems, as distinct from the end result of elegant and useful products. Design thinking results from the nature of design work: a project-based work flow around 'wicked' problems" (Dunne/Martin 2006: 517). Many global companies and players have recognised that purposeful creation and design, and associated approaches, to solve problems are essential for innovative economic activities (Brown 2008; Hofmann/Vetter 2014). Creativity, the ability to develop new ideas and to go beyond familiar patterns of thought, is an important part of innovative output. Schumpeter (2008) points out that the creation of innovations not only means the generation of new ideas in a creative sense, but in particular an adaptation to changed circumstances or user needs is the decisive impulse for this. The aim of Design thinking processes is to support creative processes in which both basic innovations in the sense of first prototypes are created. These can be aimed both at the process (improving the efficiency of the production or execution of a product/process) and at the product itself (increasing the effectiveness of the product). In addition, it is also possible to schedule Design thinking workshops in certain phases of a project in order to obtain feedback from users on a product that has already been developed as a new innovation or answer to a problem.

The boundaries of analytical and databased thinking can be progressively broken down through using Design thinking, leading to new, more innovative results. Analysis and synthesis are important components of the Design thinking process (Dym/Agogino/Eris et al. 2005; Kelley/Kelley 2014; Uebernickel/Brenner/Naef et al. 2015; Brenner/Uebernickel 2016; Weber/Rodriguez/Mateus 2016). According to Grots and Creuznacher (2012: 20) "the ultimate goal of the design thinker [...] should be to increase the quality of life of the people involved - be it customers, stakeholders or employees, [which can be achieved in particular by] improving a product, a service in terms of function, use, understanding of value or price" and thus also problem solving and innovation. Closely linked to the procedural feasibility of innovation, the desires of the users and the economic viability (Brown/ Katz 2009), the method of Design thinking is based on the three foundations of people, process and place (Grots/Pratschke 2009; Plattner/Meinel/Leifer 2018). 
People: One of the main components that design thinking is based on is the multidisciplinary team that follows the concept of T-shaping (Boland/Tenkasi 1995; Dym/Agogino/Eris et al. 2005; Kroheck 2013). This means that participants have both the technical and analytical knowledge (vertical line of the letter $\mathrm{T}$ ), as well as characteristics such as curiosity, empathy, optimism and experimentation, and the ability for team collaboration (horizontal line of the T). Through diverse teams whose actors come from interdisciplinary professional groups, and different age groups, cultural, ethnic and social backgrounds, a collective intelligence can be created, allowing the consideration of problems and issues from various perspectives (Boschma 2005; Hofmann/Vetter 2014). Therefore, a maximum of diversity, as well as a flat hierarchy and balanced, open working culture should be established at the team level (Meinel/von Thienen 2015).

Process: The aim of the Design thinking process, which can be subdivided into different phases (understanding, observing, defining one's point of view, ideating, prototyping, testing) (Sauvonnet/Blatt 2015), is to guide teams during the innovation process in such a way that both divergent and convergent thinking takes place (Brown/Katz 2009; Lindberg/Gumienny/Jobst et al. 2010; Lindberg/Noweski/Meinel 2010). The process is meant to be human-centred, with the focus of the analysis and problem definition depending on the users, and thus on the customers (Grots/Creuznacher 2012; Kroheck 2013, Benson/Dresdow 2014; Hofmann/Vetter 2014; Sauvonnet/Blatt 2015).

Place: The third important component in the Design thinking concept is the working environment. The usual office atmosphere should be interrupted by innovative and flexible concepts in the physical environment people are working in, in order to contribute to an open working culture. In particular, the variability of a workplace, but also a different atmospheric design of the place, can help to promote creativity and openness in the actors. The special room design should also ensure that team meetings can be organised, and retreat opportunities can be created for individual actors during the work process (Grots/Pratschke 2009; Kroheck 2013; Hofmann/Vetter 2014; Meinel/von Thienen 2015; Sauvonnet/Blatt 2015; Uebernickel/Brenner/Naef et al. 2015).

In addition to the strong user focus (human-centred process) and method orientation, Design thinking also exhibits limitations that must be viewed critically. Design thinking workshops are often regarded as limited time islands in normal working life. Within the every-day, fastmoving working processes, Design thinking workshops only provide a temporary break. Seitz (2017: 28) mentions that participants frequently check their e-mails or make telephone calls in the breaks of the workshops in order to be able to keep up with their work at all. In this context, the question arises as to the extent to which participants really can be led out of the rigid thinking structures within the workshops (Seitz 2017: 28). Especially as, according to Amabile (1998: 82), creativity above all "often takes time".

\section{Analytical framework: Creativity-enhancing support through people, process and place}

As Growe (2018a) argues, changing workplaces during projects can influence communication between individuals and the social dynamics in the work process (Rutten/Boekema 2012; Rutten 2014), and analysing specifically chosen physical places can reveal insights into processes and interactions occurring in these places.

Aiming to combine research concerning creativityenhancing work environments (rooted in management literature, architecture and design) with literature on temporary spatial proximity (rooted in economic geography), this study uses an analytical framework based on both perspectives. Therefore, the concept of Hoff and Öberg (2015) was combined with the different elements of the innovation method of design thinking (see Figure 1).

To understand the interrelation of social interaction and physical places mentioned in Rutten's concept (2017), different types of creativity-enhancing support (functional, psychosocial and inspirational) are used from the creativity-enhancing work environment literature (Hoff/Öberg 2015). In particular, psychosocial and inspirational support refer to the dimension of social interaction. On the other hand, the method of design thinking and its differentiation between people, process and place, as often applied in temporary settings, is used to explain the roles that physical place and social interaction play in the context of creativity-enhancing support (see Figure 1).

To analyse how far the quality of place, as well as material elements and social aspects, are a supporting trigger for knowledge creation and exchange processes, the three creativity supporting factors - psychosocial, inspirational, functional - will be connected to dimensions 


\begin{tabular}{|l|l|l|l|}
\hline & Place & Process & People \\
\hline $\begin{array}{l}\text { Psychosocial support (increase } \\
\text { well-being, decrease stress and } \\
\text { social barriers) }\end{array}$ & & & \\
\hline $\begin{array}{l}\text { Functional support (increase job } \\
\text { performance, decrease distraction) }\end{array}$ & & & \\
\hline $\begin{array}{l}\text { Inspirational support (increase } \\
\text { creativity and quality) }\end{array}$ & & & \\
\hline
\end{tabular}

Figure 1: Matrix of types of creativity-enhancing support and elements of the design-thinking method

of design thinking, specifically with its spatial (place), social (people) and dynamic (process) dimensions.

The question as to what role people, process and place play as creativity-enhancing support can be answered based on a qualitative empirical study, depending mainly on site visits and semi-structured interviews. To understand the application of the Design thinking method, desk research was also conducted.

In order to gain early insights into the application of design thinking, and the companies using design thinking as an innovation method, an internet search was carried out to find reports that informed the broader public about the method and its users. For this purpose, the search terms 'design thinking' AND 'Zeitungsberichte', 'design thinking' AND 'Zeitung', as well as 'design thinking rooms', 'design thinking workspaces' and 'design thinking' AND 'creative spaces' were used to identify companies that had integrated creativity-enhancing workspaces into their businesses, or used the method of design thinking to enhance innovation and creativity in their working processes.

In addition, the homepages of the Hasso Plattner Institute in Potsdam and of the AppHaus in Heidelberg list companies that requested Design thinking workshops as references. These lists were analysed according to company size and industry branch.

Another method developed for this study was site visits to the AppHaus in Heidelberg. The AppHaus in Heidelberg was opened to customers and visitors at the end of 2013. On an area of 400 square meters, there is a very flexible working environment as well as four different theme rooms of approximately 10 square meters each, which can be used freely during the workshops. Up to 80 people can take part in a Design thinking workshop at the same time, and up to 120 at special booked events. In addition to the AppHaus in Heidelberg, SAP operates four other houses in Palo Alto, New York (USA), Korea and Berlin, which are equipped according to the same flexible spatial concept and philosophy.

The visits focused on experiencing the attentive atmosphere of the special creativity-enhancing work environments. By gathering a variety of impressions inside the rooms, and developing different methods of one's own, we got a clearer idea of the unusual materials used in the Design thinking approach, like for example building blocks, dough, straws and crumple balls. Furthermore, we attended an in-depth Design thinking workshop, organised by the GPM ${ }^{1}$ Young Group of the Rhine-Neckar Metropolitan Region. The aim of this participation was not only to theoretically capture the method of design thinking, but to experience it in practical application. With the help of theoretical background knowledge from the literature, it was possible to be able to understand the individual phases of the innovation process in more detail, and to recognise their relevance in the entire process.

Two visits to the AppHaus in Heidelberg followed, one undertaken with a guided tour that provided initial impressions on the subject. This visit allowed us to experience the special atmosphere of the room, as well as the open-space concept, and the different materials and elements used in the entire innovation process. The second visit was made through participation in a Design thinking workshop, developing ideas for the creation of a new urban quarter over the course of two days.

Guidelines for the observation covered the participants' interactions with each other and with the physical environment, including the use of materials provided in the workspace. The main aim was to observe workshop participants and their reactions to the carefully designed physical environment. In addition, particular attention was paid to whether the individual participants exchanged views on the special atmosphere created by the room. This provided a first idea of the participants' appraisals of the individual materials in the physical work environments, the methods provided by the coaches and the different team environments as such.

For this study, semi-structured qualitative expert interviews were conducted with stakeholders offering and participating in design-thinking workshops (see

1 Deutsche Gesellschaft für Projektmanagement 
Table 2: Interview partners

\begin{tabular}{llll}
\hline Interview partner & Sex & Interview period & Interview mode \\
\hline Workshop facilitator \#1 & Male & 75 minutes & face-to-face \\
Workshop facilitator\#2 & Male & 45 minutes & Telephone \\
Workshop facilitator\#3 & Male & 40 minutes & face-to-face \\
Workshop participant \#1 & Female & 84 minutes & face-to-face \\
Workshop participant \#2 & Male & 80 minutes & face-to-face \\
Workshop participant \#3 & Male & 54 minutes & face-to-face \\
\hline
\end{tabular}

Table 2). The process of accessing interviewees was challenging. The aim of the empirical survey was to interview actors who were still in the innovation process itself, or who had only recently completed it to avoid an ex-post construction of legitimation or memory. The limitation here was that only a few actors were willing to provide information about their new and not yet finalised ideas and about prototyping during the innovation process. Economic actors were especially cautious not to reveal details about prototyping during creativity-enhancing workshops. In order to gain insights about the interrelations of the physical environment, actor constellations and interaction processes, a smaller number of interviews had to be accepted as sufficient. In addition, interviewees from a non-economic background were selected. The selected workshop participants were concerned with strategy development and the generation of new ideas in urban planning contexts and in the third sector.

The interviews were conducted in 2017, in German the mother tongue of the interviewees and interviewers - and translated into English for this paper. All selected interviewees were first contacted by e-mail. Each of the interviews took between one and two hours. The interviews followed open interview guidelines with narrative elements. Semi-structured and problemcentred interviews were chosen to allow the respondents to answer freely, and so they were influenced as little as possible by the interviewer, enabling the interviewer to cover the intended topics, and giving the interviewee freedom in the order of the proceedings (see Mayring 2010). This open approach was followed by an individual questionnaire, adapted to the course of the conversation, which allowed new questions to emerge. Partial standardisation as a guide to the interview also enabled all relevant topics to be processed in an unspecified order, thus ensuring the interviews were clearly comparable.
The interviews were conducted with Design thinking workshop participants, as well as with workshop facilitators. Workshop participants were selected who had visited the AppHaus in Heidelberg with their organisation, and whose focus extended beyond economics, as these participants were more open to revealing details of the work process. The workshop facilitators included a Design thinking coach from the AppHaus, a provider that sells Design thinking workshops and mobile creative spaces and thus the aspect of place to companies, and a young professional from a creative management consultancy. The interviewees were identified by a propagation system, using the contact information of the Design thinking coach from the AppHaus, personal contacts and internet research.

All interviews were recorded and transcribed. The transcripts were analysed through a process of coding and categorisation of meanings. The topics covered were design thinking as an innovation method, the importance of workplace environments for creative and innovation processes, and the meaning of place in general, as well as proximity/distance and interaction between participants. The interviews started with a relatively open question ('Could you please tell me something about the philosophy of your organisation and the everyday working processes used?'), and then moved on to more specific questions. Examples of further questions are 'To what extent are other places and work environments helpful in breaking up habitual thinking structures?' and 'In what way do you change environments during your projects, and why?' The wording and order of these general questions were adapted to the specific interview situation. For the analysis, relevant aspects were extracted from the interviews and grouped among predefined and constantly adjusted coding categories, mirroring the topics covered (e.g., work environments, interaction phases, innovation methods). 


\section{Empirical results: Design thinking as a supportive mechanism for creative processes}

The desk research showed that the method of design thinking is used with increasing frequency, and across many industries. Enterprises and firms from various branches (science and education, insurance, automotive industry, financial services, food industry, energy, healthcare, transportation and infrastructure, politics, sports, music, IT), as well as church institutions and municipalities, had enquired about workshops at the AppHaus. In addition, newspaper articles also showed the significance of creativity-enhancing spatial concepts and innovative methods across the various industry branches (o.V. 2010; Endres/Rohwetter 2016; Klaaßen 2017). The enterprises and other institutions had completely different problems, enquiries and, therefore, also expectations in relation to the workshops. Furthermore, the size of the enterprises also varied a lot. However, all firms were alike in seeking creative, tailored solutions to specific problems and user needs. Based on the results of the desk research, hypotheses were developed that both social space and physical place, and therefore creativity-enhancing environments, are important in all knowledge-based and innovative industries.

The empirical results of the interviews, with regard to the question concerning what role people, processes and places play as creativity-enhancing support, were organised according to a nine-fold scheme, presenting the results to each combination of creativity-enhancing support with the three elements of the design-thinking method. The presented results mainly depend on interview materials and site visits. Further findings from the desk research support the results of the nine-fold scheme.

\subsection{Psychosocial support}

According to the concept of Hoff and Öberg (2015), particular features ensure that well-being during working processes can be increased, and that stress and social barriers can be reduced (psychosocial support). Crucial in this context is trust, as an important resource for stakeholder interaction, and to support knowledge sharing, learning and innovation (Fulmer/Gelfand 2012;
Growe 2018b). Trust between individuals is especially supported by (temporary) physical proximity, and supports further interactions (Costa/Fulmer/Anderson 2018). Therefore, trust comes into play in all three dimensions of the Design thinking concept - place, process and people.

\section{Psychosocial support through place}

Besides the location and the sole co-presence of the actors themselves, the quality of place as psychosocial support also plays an important role. In particular, spaces of interaction and communication, but also private spaces, which can be used for participating in different types of teamwork or individual work, have a positive effect on the creative process (Uebernickel/ Brenner/Naef et al. 2015). In particular, the flexible spatial concept has shaped the method of design thinking, and is described as being particularly supportive for innovation processes: "In my school, we say: The first teacher is the student [themselves], the second teacher is the classmate, the third teacher is the room, the fourth teacher is the teacher. The [AppHaus] depict[s] the importance of space. And by providing exercise rooms with gym equipment or rooms with cool sofas, in which quick changes can be made with pin boards [...], where you can easily present, where you can also try something out, the room 'teaches'" (Workshop participant \#1).

Furthermore, rooms can also support contact with other employees through special design and open spatial concepts, promoting exchange and helping to familiarise actors with one another. Thus not only the relationship in which the individual employees relate to each other is crucial, but also whether they are located, for example, in great cognitive or social proximity. Employees are given psychosocial support, for example through stress management spaces, or spaces for connection and communication, in order to get in touch and, if necessary, also create random contacts, which are referred to as local buzz (Rutten 2017; Growe 2018a). "It makes sense to me to design rooms differently, and also to have rooms designed by more up-to-date office concepts. But also to have free spaces that one can book in and out of because, with the room, I also stage something else. For example, I usually work with the door open, unless I have a meeting. And then I have another [contact], then people will come in and I'll suddenly have a conversation with them" (Workshop participant \#1).

\section{Psychosocial support through process}

In general, the iterative process of design thinking, which is subdivided into six phases, also helps to build 
trust. At the beginning of the Design thinking workshops, workshop participants will be introduced to the concept, as such, as well as to the phases. As a result, a certain horizon of expectation is developed, and the participants can gain confidence in the method. Luhmann (2000) understood trust to be a mechanism reducing both the complexity of systems and issues. As a result, the expectations of the actors stabilise, and uncertainties are reduced. "[The process] was briefly explained. Of course, at least the first time, more in detail, the second time a bit shorter, because some participated for the second time" (Workshop participant \#2).

Apart from this, the people who participate in Design thinking workshops can also have a psychosocial effect on the creativity process. In the individual phases of the multidimensional iterative Design thinking process, a wide variety of methods is used and, in addition, various rooms are visited. Hierarchy levels within the team should be broken up, for example, by certain welcome rituals at the beginning of the process. "There is an initiation ritual. The moderator was very good. At the beginning, he, as the boss, personally greeted us all. So, I perceived him as a boss. He personally gave us a badge with our name on it. I thought it was a good initiation ritual - now you're one of us, move around in this room, get a cup of coffee here, go ahead, there are some nuts to eat. Like - enjoy yourself first" (Workshop participant \#1).

These rituals, which are also closely linked to the application of different methods, are managed by the Design thinking coaches. The process conveys a special culture, characterised in particular by openness, curiosity and no prohibition to thinking. Without guidance from an experienced coach, and the different social embeddednesses of the participants, this process cannot take place. "To be on an equal level, that could have been done better. There were good moderators who did that and there were also bad moderators who didn't do that. [...] I think it's the job of the moderators that the conversations work on an equal level" (Workshop participant \#3). Through this ritual being part of the process at the beginning of the workshop, and the flexibility of the space, a flat hierarchy in the team, between the individual participants, is achieved.

\section{Psychosocial support through people}

Furthermore, psychosocial support is also provided. Namely, confidence in one's own creativity is strengthened by the moderating staff. "[It's] the confidence in your own creativity [...] - 'the creative confidence'. [...] We try to teach people: You can solve a problem on your own! Combined with: I have a trustful environment, where I can maybe try things out, try myself, and no one laughs" (Workshop facilitator \#1). Also participants emphasised that it is especially important to feel cognitively and socially close to other participants, so that one could work in a fearless environment and let thoughts run free (Meinel/von Thienen 2015). "That's what I meant earlier with 'spaces free of fear'. So I have to have the courage to develop an immature opinion because, if everyone passes on only secured knowledge, then there's no new knowledge creation" (Workshop participant \#2). The quotes illustrate increased well-being and a decreased stress level as well as reduced social barriers as psychosocial support in the creative process.

\subsection{Functional support}

Due to the functional dimensions of the work environment, such as rooms where no further influences can disturb your working processes, the creative process can be promoted and supported, according to the concept of Hoff and Öberg (2015). Differentiating functional support according to the dimensions of design thinking, it becomes obvious that it is not only the place that can increase the effectiveness of the work process and reduce distraction. Rather, the organisation of the process and the people involved also play a crucial role.

\section{Functional support through place}

The dimension of place includes different spatial concepts, used at different stages in the Design thinking process. In this context, open group areas, smaller teamwork areas, flexible individual work areas, as well as permanently assigned individual workplaces can be distinguished (Uebernickel/Brenner/Naef et al. 2015). It is important in the entire innovation process to exclude all exogenous influences, such as laptops and telephones, so that these exogenous factors cannot disturb the flow of creativity. Workshop facilitators in particular consider the aspect of undisturbed privacy as essential to the success of the Design thinking process, and argue that the interior design can be very helpful in reducing disturbances. "When you're in other rooms, like when you're on vacation, maybe you behave differently, too. Because the environment influences your behaviour. You can get involved better in new things and thoughts. You may also be able to work in a more focused way on the topic because you simply do not have a desk where you constantly work on your e-mails, or no colleagues can constantly annoy you" (Workshop facilitator \#1). 
The importance of the possibility to retreat from the everyday working context is also confirmed in the literature (see Growe 2018a). However, not only the bare possibility to retreat is important here, but the possibility to work in a specific place with a work-supporting environment that, however, may differ between the work processes (Flögel/Zademach 2017; Growe/Mager 2018). "The physical environment is important. It's important that there [in the AppHaus] ${ }^{2}$ is a practice room with gymnastics equipment or cool sofas, with flexible tools, with pin boards that can be moved around, with which you can present easily, with which you can also try something out. I think, that in itself, teaches, too. If I design rooms unusually or always leave garbage on the floor - it all has an effect. Whether I am aware of it or not" (Workshop participant \#1).

\section{Functional support through process}

In order to optimise the output and the flow of the creativity process, it is necessary to consider the iterative process functionally. Depending on which projects are to be undertaken, the methods used, as well as the process phases of the Design thinking workshops, were customised in a preliminary interview, and adapted to the needs and problems of the respective questions. Through these tailor-made innovation phases, the participants could be directly appealed to. "It [the process, author comment] is actually adjusted in each case. Above all, you can actually $[\ldots]$ start at each of the six stages. [...] The subordinate terms 'discover', 'design', 'deliver' are actually always available in the process" (Workshop facilitator \#1).

Therefore, it is important to create open spaces in the process itself, in which it is allowed to make mistakes and learn from them. The focus here is on creating an open atmosphere through the design of the room, but also through appropriate methods and creativity techniques (e.g. brainwriting techniques, storytelling, creating mock-ups or empathy maps) (Sauvonnet/Blatt 2015), eliminating limitations in the process of thinking: "The SAP people moderate that. The first thing in the first workshop was not to describe what is feasible, but to really think further. And I think that's the opportunity. We don't have this permission in our normal, daily business" (Workshop participant \#1).

\section{Functional support through people}

The third pillar of the Design thinking concept people - can also support the creative process in a

2 authors' comment functional sense. Functional support of the creative process through people is enabled through key qualifications and prerequisites, guaranteeing openness and respect towards other participants. Acceptance and respect for the different disciplines of the participants and, thus, their experiences, competencies and abilities, are also expressed in trust in one's own and other's competencies (Growe 2018a; Growe 2018b). Actors should not remain stuck in their discipline, but instead should try to take information and new ideas from their interdisciplinary cooperation in the workshoprelated non-hierarchical space. "One should definitely move out of one's normal comfort zone. One should try to work actively and under time pressure. [...] Often, it is about developing the core idea first, and worrying about the details later. And to be able to interact with people from different backgrounds, and appreciate them, too" (Workshop facilitator \#3).

The functional aspect, with regard to people, is mainly about interaction possibilities between actors of different social and cognitive backgrounds allowing an exchange of different views on a specific topic. This results in an enlargement of ideas and visions, enabling new individual solutions to be found, leading to creative innovation. "In the end, it's the people who make the difference. Methods are, at best, tools to help. [...] That is why we try to build a trustful atmosphere and a personal atmosphere; that one does not say, this is $\mathrm{Mr}$. $X$, who has function A and that is Mr. Y, but instead say, that is Peter and that is Mark and [...] these are people with these advantages and disadvantages, and we work together as different people, not with anonymous formal functions" (Workshop facilitator \#1).

Apart from the creative results of the process, another huge benefit for many companies is the building of new networks among various employees who otherwise would not work together, or would not know each other personally in large firms. Actors might do a workshop together and, with regard to developing certain ideas further, some results are produced. However, the biggest benefit for the company in the end is people leaving the workshop and saying, "Ah, wait - the guy from the marketing team, he's very kind, and we always thought they were idiots" (Workshop facilitator \#2).

\subsection{Inspirational support}

The third creativity-enhancing support discussed in the concept of Hoff and Öberg (2015) is inspirational support. The following section argues that not only the space, 
but also process and people - as part of the Design thinking method - can be supportive in an inspirational sense, although the most obvious inspirational support is created by specifically designed places.

\section{Inspirational support through place}

One of the most important, and visually most obvious, elements in the concept of design thinking is the special working environment and the space especially equipped to carry out this innovation method. "The factor of place, that is a very important factor, and in one company, we once considered designing the entrance [to a Design thinking room, author comment] accordingly. [...] There was a Design thinking room at the top of the building, where you had a perfect view of the whole city. The room was also fully glazed. So we thought, Ok, we will build an entrance area that looks like when you get on a plane. Where people go through, just to leave the normal working context behind them" (Workshop facilitator \#3).

Here, not only does the unusual atmosphere play a special role in itself, but unusual materials that are rarely used in everyday working contexts can also help to break through well-worn and habitual thought patterns (see also Growe/Mager 2018). "Of course, that's inspiring other furniture, other smells, other.... It feels different. Of course, that somehow inspires and it clears the mind. That is like being on holiday. [...] The environment can influence you. [...] I think it would have to be lightcoloured, there has to be room to move around. We like to work standing, not sitting, and because we like to work visually, we need walls we can put the information on" (Workshop facilitator \#1).

Important in this context is that the place used to create inspirational support has to be constantly changed. A room that looks the same for many meetings will lose its inspirational support, as it cannot stimulate ongoing curiosity. "My observation is that a creative room that looks exactly the same as you left it perhaps half a year ago has actually lost its effectiveness. Because the room no longer contains elements of surprise. In other words, to keep a creative room working, you constantly have to change it dynamically" (Workshop facilitator \#2).

Thus, temporality plays a crucial role in providing inspirational support (Growe/Mager 2018). This goes hand in hand with the concept of eventisation, which is also based, among other things, on temporary spatial proximity and supports information exchange through symbolic constituent parts (Lange/Power/Suwala 2014).

\section{Inspirational support through process}

Similarly to the unusual design of space, extraordinary tools are also used throughout the process to break up the well-known everyday work atmosphere and create a stimulating field of interaction. "In my experience, what helps most is just the core virtue of design thinking - 'be visual'. So, do not talk about it for long, just roll up your sleeves, and then you'll build, draw or cobble something together" (Workshop facilitator \#1).

To inspire creativity throughout the process, the toolkit of design thinking offers, in addition to methods such as body storming, spaghetti tower or benchmarking (Uebernickel/Brenner/Naef et al. 2015), the possibility to adapt methods directly to the respective project, and thus to the customer. The workshop participants particularly emphasised the tailored use of methods. For example, metaphors were used and developed in the workshops which the participants could easily connect and associate with different ideas. Here, also, a certain kind of eventisation of the innovation process takes place. According to Burzan (2017), a process has to activate the participants, and offer interlinkages to everyday habits, in order to be called an event (see also Gebhardt/Hitzler/Pfadenhauer 2000; Hitzler 2011): "They have adapted the processes for us. [...] We had such a cool metaphor with a boat. [...] We could copy that perfectly into our work context [a religious work context, author comment]. So, our people jumped on it very easily" (Workshop participant \#1).

Adjusting the applied methods according to the workshop participants is not only helpful for the creative processes, but is also necessary to avoid conflict. For example, not all participants are able or willing to use the same method. "Of course, one has to be careful. There were seasoned and experienced personalities in the workshop. Thus, the moderators had to accept not to play with toy blocks with these personalities. The moderators had to be flexible enough to say, Ok - we shortened the process just now. We already have results" (Workshop participant \#2).

Some approaches might not be accepted (immediately) by all participants, thus leading to discussions about the methods instead of about the content. "At the second workshop, everyone should create a fictional jubilee brochure and imagine the house [project discussed in the workshops, author comment] in five years. This was a very exiting process, revealing many different understandings of the project. The most critical voice raised in this process was from one elderly female participant, like 'they want to brainwash us. They 
Eventisation through an inspiring work atmosphere in temporary proximity

\begin{tabular}{|l|l|l|l|}
\hline & Place & Process & People \\
\hline $\begin{array}{l}\text { Psychosocial support (increase } \\
\text { well-being, decrease stress and } \\
\text { social barriers) }\end{array}$ & $\begin{array}{l}\text { Open space designed to } \\
\text { create familiar and also inte- } \\
\text { resting atmosphere }\end{array}$ & $\begin{array}{l}\text { Process is well-structured and } \\
\text { creates trust }\end{array}$ & $\begin{array}{l}\text { Initial ritual establishes feeling } \\
\text { of equality and freedom from } \\
\text { anxiety }\end{array}$ \\
\hline $\begin{array}{l}\text { Functional support (increase job } \\
\text { performance, decrease distraction) }\end{array}$ & $\begin{array}{l}\text { Protection of working envi- } \\
\text { ronment }\end{array}$ & Tailored methods & $\begin{array}{l}\text { T-shaped people concept } \\
\text { minimises conflict }\end{array}$ \\
\hline $\begin{array}{l}\text { Inspirational support (increase } \\
\text { creativity and quality) }\end{array}$ & $\begin{array}{l}\text { Unusual materials break up } \\
\text { habitual working structures }\end{array}$ & $\begin{array}{l}\text { Exceptional working methods } \\
\text { break up habitual working } \\
\text { structures }\end{array}$ & $\begin{array}{l}\text { Face-to-face interaction in } \\
\text { temporality }\end{array}$ \\
\hline
\end{tabular}

Figure 2: Matrix of types of creativity-enhancing support applied in the innovation method of design thinking

want us to imagine that it works. But it cannot work'" (Workshop participant \#1). Above all, people's openness, curiosity and horizon of expectation play a decisive role here, and must be curated carefully.

\section{Inspirational support through people}

Inspirational support of the creative process through people is mainly reached in multidisciplinary ways. The multidisciplinary team, a basic requirement in design thinking, supports working creatively and with inspiration. On one hand, multidisciplinary teams allow the coming together of people who have not previously worked together in other contexts. Different experiences and the different social embeddedness of the actors can lead to different perspectives, and to the development of diverse solutions. Furthermore, hierarchical boundaries become blurred due to the different educational backgrounds of the participants. Thus, lock-in effects are avoided. "I once had a workshop at a university where students and professors were mixed in teams, and that worked amazingly well. [...] Of course, putting the teams together, you aim to enable everyone to contribute. For example, if you want to develop a new app, and maybe you have an IT professor and a business administration student, then the business administration student can also tell the IT professor something. [...] My experience, so far, has always been rather positive, in the sense that hierarchy levels tend to disappear and the actors work really well together" (Workshop facilitator \#3).

In order to maintain this inspiring atmosphere among the different disciplines, it is important that the participants interact only temporarily and, therefore, for a limited time. If the participants repeatedly exchange ideas with the same people in the same team over a long period of time, the different views will no longer be new and will thus lose their inspirational and creative momentum. "There was a small universe of Heidelberg in the AppHaus. People met there, that one would generally wish for in other circumstances. Meeting the different worlds, the different milieus, the different disciplines can be an innovation driver" (Workshop participant \#3).

\section{Discussion: How can quality of place and, as a result, the social environment influence creativity?}

This paper had the goal of analysing how far the quality of place is a supporting condition for triggering knowledge creation and exchange processes beyond the (in geography) much-studied elements of people and process. According to Rutten (2017), quality of place refers to material elements (how is the place designed, and what material elements can be found there?), as well as to social aspects (who is acting in the places, and what processes are carried out there?). Therefore, the conceptualisation following Hoff and Öberg (2015) was applied to the various Design thinking elements of place, process and people. Components offering psychosocial (increase well-being, decrease stress and social barriers), functional (increase job performance, decrease distraction) and inspirational (increase creativity and quality) support could be found in the whole design-thinking process (see Figure 2).

The meeting of different actors in co-presence promotes exchange relations among them. Nonverbal communications, such as facial expressions and gestures, of the other people become visible, and can be interpreted in combination with what has been said. For this, a familiar, but also an interesting, atmosphere in a protected working environment can be very helpful (see, e.g., psychosocial support/people and psychosocial support/place). This holistic view of the statements reduces uncertainty and risk not only in exchange actions of high specificity. Even actors who do not know each other personally can learn to appreciate one another better in co-presence (Growe 2018b). Also, the well-structured process of design thinking creates trust between the participants (see, e.g., psychosocial support/ process). In addition, visualisation and materiality play an 
important role in order to structure thoughts and narrow down ideas, and make them understandable (see, e.g., inspirational support/process and inspirational support/ place). These visualisations, and also exercises related to team dynamics, can only take place in face-to-face encounters.

Innovation processes in creativity-enhancing workspaces are subject to a sort of eventisation. The generation of knowledge in such spaces predominantly depends on special methods, such as the Design thinking approach and the expectation of doing something exciting and new (see, e.g., inspirational support/ place and inspirational support/process). According to Burzan (2017), first, the aspect of emotionalisation plays a crucial role in eventisation. The face-to-face interaction in temporary spatial proximity has a certain emotional aspect as well, because the social space and the physical place are always indispensably interwoven (see, e.g., psychosocial support/people). The T-shaped team is embedded in different personal and professional contexts, which leads to manifold experiences and ideas, as well as to different opinions and approaches. The second criterion for eventisation, according to Gebhardt/ Hitzler/Pfadenhauer (2000), Betz/Hitzler/Pfadenhauer (2011) and Hitzler (2011), is that the participants can link the new experiences to their everyday lives and working processes. An example of this is that the different methods in the innovation process are tailored to the participants in order to facilitate the knowledge generation process (see, e.g., functional support/process and functional support/people).

The flexibility and atmosphere of Design thinking spaces thus helps to support creative work processes. Cultural economic geography advocates the thesis that, when considering social interactions, workplaces have to be analysed by microgeographical studies, since work fills a large part of everyday life (Ettlinger 2003). Workplaces and private life are becoming increasingly interwoven, which in turn is another argument for the creativity-supporting effect of events in different working places. The special design of the rooms helps creative professionals to break out of the normal, everyday working environment. Habitual structures of thinking can be left behind, thus promoting creativity. Important here is that the methods are used only temporarily, and change between the different spatial concepts. For example, the different architectural designs of rooms or different room concepts (meeting rooms or rooms for individual work) create a different atmosphere and thus trigger different emotions while using these rooms (Pallasmaa 2014; Willenbrock 2014). A room with a jungle-like atmosphere, for example, can trigger different emotions and thoughts than a wide-open room with a view, designed to resemble an airplane. So, the effect and the eventisation of the place is retained, and the event always retains something new for the creators (see, e.g., inspirational support/ people) (see also Schüßler/Grabher/Müller-Seitz 2015). Besides, the Design thinking workshops are limited in time. They lift the participating actors out of their daily working routine and the application of different methods and materials creates a special atmosphere (e.g. opening rituals as a trust-building method). In addition to the existence of creativity-enhancing workplaces, temporary spatial proximity also plays a crucial role in continually promoting creativity. Following Rutten (2017), it is necessary that continuous exchange takes place between the physical place - the creativity-enhancing workspace - and the social space - the creative workers - in order for the innovation process to be carried out. Therefore, the creation of knowledge is linked to both the social space and the physical place, and is influenced by steady socio-spatial dynamics. If there are no creative spaces available in the enterprises, a change of location or booking a conference room or coworking space, can help to engender new ways of thinking (Growe 2018a; Growe/Mager 2018).

To conclude, the matrix in Figure 2 indicates that three supporting aspects (place, process and people) support creativity in three different ways (psychosocial support, functional support, and inspirational support). However, it is important to stress that there are intermediate relations. Elements of place may support creativity in a psychosocial and in an inspirational way. The different kinds of creativity support frequently cannot be separated accurately. Therefore, an important result is that all three supporting aspects (place, process and people) have been mentioned in the interviews as supporting creativity, and the three types of creativity support (psychosocial support, functional support and inspirational support) could be confirmed through the interviews, too.

The interlinkage of physical place and social space in creative work processes opens up avenues for further research in two directions. First, the importance of the temporary use of specifically created places in working processes could bridge the gaps between urban and economic geography through bringing the advantages of multiple and diverse places in processes of creative value creation into focus. Research strands dealing with eventisation (Gebhardt/Hitzler/Pfadenhauer 2000; Betz/ Hitzler/Pfadenhauer 2011) from an urban geography perspective, and with temporary clusters and events 
(Maskell/Bathelt/Malmberg 2006; Henn/Bathelt 2015) from an economic geography perspective, could be combined here. Second, from a policy and planning perspective, it is necessary to shed light on different regional preconditions and possible policy implications. If enhancing creativity is supported by the temporary use of multiple and various places, access to a diversity of places becomes crucial. Questions arise about whether this diversity of places should be in the permanent co-location of creative workers (arguing for further spatial concentration processes in agglomerations) or if the temporary use of multiple and various places can also be accessed through travelling (arguing for possible deconcentrating processes, if transport infrastructure is sufficient).

\section{References}

Allen, T.J.; Henn, G.W. (2007): The organization and architecture of innovation. Managing the flow of technology. Amsterdam.

Amabile, T. (1998): How to kill Creativity. In: Harvard Business Review 76, 5, 76-86.

Amabile, T.M.; Pratt, M.G. (2016): The dynamic componential mode of creativity and innovation in organizations: Making progress, making meaning. In: Research in Organizational Behavior 36, 157-183. doi: 10.1016/j.riob.2016.10.001

Amin, A. (2004): Regions Unbound: Towards a new Politics of Place. In: Geografiska Annaler: Series B, Human Geography 86, 1, 33-44. doi: 10.1111/j.0435-3684.2004.00152.x

Asheim, B.; Coenen, L.; Vang, J. (2007): Face-to-Face, Buzz, and Knowledge Bases: Sociospatial Implications for Learning, Innovation, and Innovation Policy. In: Environment and Planning C 25, 5, 655-670. doi: 10.1068/c0648

Bathelt, H.; Gibson, R. (2015): Learning in 'Organized Anarchies': The Nature of Technological Search Processes at Trade Fairs. In: Regional Studies 49, 6, 985-1002. doi: 10.1080/00343404.2013.783691

Bathelt, H.; Henn, S. (2014): The geographies of knowledge transfers over distance: toward a typology. In: Environment and Planning A 46, 6, 1403-1424. doi: 10.1068/a46115

Bathelt, H.; Malmberg, A.; Maskell, P. (2004): Clusters and knowledge: local buzz, global pipelines and the process of knowledge creation. In: Progress in Human Geography 28, 1 , 31-56. doi: 10.1191/0309132504ph469oa

Bathelt, H.; Schuldt, N. (2008): Between Luminaires and Meat Grinders: International Trade Fairs as Temporary Clusters. In: Regional Studies 42, 6, 853-868. doi: 10.1080/00343400701543298

Bathelt, H.; Schuldt, N. (2010): International Trade Fairs and Global Buzz, Part I: Ecology of Global Buzz. In: European Planning Studies 18, 12, 1957-1974. doi: 10.1080/09654313.2010.515815

Bathelt, H.; Turi, P. (2011): Local, global and virtual buzz: The importance of face-to-face contact in economic interaction and possibilities to go beyond. In: Geoforum 42, 5, 520-529. doi: 10.1016/j.geoforum.2011.04.007
Benson, J.; Dresdow, S. (2014): Design Thinking. A Fresh Approach for Transformative Assessment Practice. In: Journal of Management Education 38, 3, 436-461. doi: $10.1177 / 1052562913507571$

Betz, G.J. (2018): Idealtypologie der Zwischenräume. Typenbildung hybrider Graubereiche am Beispiel inszenierter Ereignisse. In: Burzan, N.; Hitzler, R. (eds.): Typologische Konstruktionen. Prinzipien und Forschungspraxis. Wiesbaden, 95-111. doi: 10.1007/978-3-658-21011-3

Betz, G.; Hitzler, R.; Pfadenhauer, M. (eds.) (2011): Urbane Events. Wiesbaden. doi: 10.1007/978-3-531-92902-6

Boland, R.J.; Tenkasi, R.V. (1995): Perspective Making and Perspective Taking in Communities of Knowing. In: Organization Science 6, 4, 350-372.

Boschma, R. (2005): Proximity and Innovation: A Critical Assessment. In: Regional Studies 39, 1, 61-74. doi: 10.1080/0034340052000320887

Brenner, W.; Uebernickel, F. (eds.) (2016): Design Thinking for Innovation. Research and Practice. Cham. doi: 10.1007/9783-319-26100-3

Brown, T. (2008): Design Thinking. In: Harvard Business Review 86, 6, 84-95.

Brown, T.; Katz, B. (2009): Change by design. How design thinking transforms organizations and inspires innovation. New York.

Burzan, N. (2017): Eventisierung als Erscheinungsform hybrider Ereignisse? In: Betz, G.J.; Hitzler, R.; Niederbacher, A.; Schäfer, L. (eds.): Hybride Events. Zur Diskussion zeitgeistiger Veranstaltungen. Wiesbaden, 219-231. doi: 10.1007/978-3658-16825-4

Castells, M. (2010): Globalisation, Networking, Urbanisation: Reflections on the Spatial Dynamics of the Information Age. In: Urban Studies 47, 13, 2737-2745. doi: 10.1177/0042098010377365

Ceylan, C.; Dul, J.; Aytac, S. (2008): Can the office environment stimulate a manager's creativity? In: Human Factors and Ergonomics in Manufacturing and Service Industries 18, 6, 589-602. doi: 10.1002/hfm.20128

Cohendet, P.; Grandadam, D.; Simon, L.; Capdevila, I. (2014): Epistemic communities, localization and the dynamics of knowledge creation. In: Journal of Economic Geography 14, 5, 929-954. doi: 10.1093/jeg/lbu018

Costa, A.C.; Fulmer, C.A.; Anderson, N.R. (2018): Trust in work teams: An integrative review, multilevel model, and future directions. In: Journal of Organizational Behavior 39, 2, 169184. doi: $10.1002 /$ job. 2213

Csikszentmihalyi, M. (2010): Creativity. Flow and the psychology of discovery and invention. New York.

Dul, J.; Ceylan, C. (2011): Work environments for employee creativity In: Ergonomics 54,1, 12-20. doi: 10.1080/00140139.2010.542833

Dul, J.; Ceylan, C. (2014): The Impact of a Creativity-supporting Work Environment on a Firm's Product Innovation Performance. In: Journal of Product Innovation Management 31, 6, 1254-1267. doi: 10.1111/jpim.12149

Dul, J.; Ceylan, C.; Jaspers, F. (2011): Knowledge workers' creativity and the role of the physical work environment. In: Human Resource Management 50, 6, 715-734. doi: 10.1002/ hrm.20454

Dunne, D.; Martin, R. (2006): Design Thinking and How It Will Change Management Education: An Interview and Discussion. 
In: Academy of Management Learning and Education 5, 4, 512-523. doi: 10.5465/amle.2006.23473212

Dym, C.L.; Agogino, A.M.; Eris, O.; Frey, D.D.; Leifer, L.J. (2005): Engineering design thinking, teaching, and learning. In: Journal of Engineering Education 94, 1, 103-120. doi: 10.1002/ j.2168-9830.2005.tb00832.x

Endres, A.; Rohwetter, M. (2016): Bürogestaltung. Gute Arbeit, Leute! In: Die Zeit Nr. 46 vom 3. November 2016, 21.

Ettlinger, N. (2003): Cultural economic geography and a relational and microspace approach of trust, rationalities, networks, and change in collaborative workplaces. In: Journal of Economic Geography 3, 2, 145-171. doi: 10.1093/jeg/3.2.145

Flögel, F.; Zademach, H.-M. (2017): Bank branches as places of knowledge creation: conceptual considerations and empirical findings at the micro-geographical scale. In: Erdkunde 71, 4, 301-312. doi: 10.3112/erdkunde.2017.04.03

Florida, R.L. (2006): The rise of the creative class. And how it's transforming work, leisure, community and everyday life. New York.

Fulmer, C.A.; Gelfand, M.J. (2012): At What Level (and in Whom) We Trust. Trust Across Multiple Organizational Levels. In: Journal of Management 38, 4, 1167-1230. doi: 10.1177/0149206312439327

Gebhardt, W.; Hitzler, R.; Pfadenhauer, M. (2000): Events. Wiesbaden.

Gertler, M.S.; Levitte, Y.M. (2005): Local Nodes in Global Networks: The Geography of Knowledge Flows in Biotechnology Innovation. In: Industry and Innovation 12, 4, 487-507. doi: 10.1080/13662710500361981

Glückler, J. (2007): Economic geography and the evolution of networks. In: Journal of Economic Geography 7, 5, 619-634. doi: 10.1093/jeg/lbm023

Grabher, G. (2002): Cool Projects, Boring Institutions: Temporary Collaboration in Social Context. In: Regional Studies 36, 3, 205-214. doi: 10.1080/00343400220122025

Grabher, G. (2004): Learning in Projects, Remembering in Networks? Communality, Sociality, and Connectivity in Project Ecologies. In: European Urban and Regional Studies 11, 2, 103-123. doi: $10.1177 \% 2 F 0969776404041417$

Grabher, G.; Ibert, O. (2017): Knowledge Collaboration in Hybrid Virtual Communities. In: Bathelt, H.; Cohendet, P.; Henn, S.; Simon, L. (eds.): The Elgar Companion to Innovation and Knowledge Creation. Cheltenham, 537-555.

Grabher, G.; Melchior, A.; Schiemer, B.; Schüßler, E.; Sydow, J. (2018): From being there to being aware: Confronting geographical and sociological imaginations of copresence. In: Environment and Planning A 50, 1, 245-255. doi: 10.1177/0308518X17743507

Grandadam, D.; Cohendet, P.; Simon, L. (2013): Places, Spaces and the Dynamics of Creativity: The Video Game Industry in Montreal. In: Regional Studies 47, 10, 1701-1714. doi: 10.1080/00343404.2012.699191

Grots, A.; Creuznacher, I. (2012): Design Thinking: Prozess oder Kultur? Drei Fallbeispiele einer (Veränderungs-)Methode. In: Organisationsentwicklung 31, 2, 14-21.

Grots, A.; Pratschke, M. (2009): Design Thinking - Kreativität als Methode. In: Marketing Review St. Gallen 26, 2, 18-23. doi: 10.1007/s11621-009-0027-4

Growe, A. (2018a): Buzz at workplaces in knowledge-intensive service production: Spatial settings of temporary spatial proximity. In: European Urban and Regional Studies. doi: 10.1177/0969776418784999

Growe, A. (2018b): Developing trust in face-to-face interaction of knowledge-intensive business services (KIBS). In: Regional Studies. doi: 10.1080/00343404.2018.1473567

Growe, A.; Mager, C. (2018): Changing workplaces in the creative process in creative industries - The case of advertising and music. In: Erdkunde 72, 4, 259-271. doi: 10.3112/ erdkunde.2018.04.01

Haner, U.-E. (2005): Spaces for Creativity and Innovation in Two Established Organizations. In: Creativity and Innovation Management 14, 3, 288-298. doi: 10.1111/j.14768691.2005.00347.x

Henn, S.; Bathelt, H. (2015): Knowledge generation and field reproduction in temporary clusters and the role of business conferences. In: Geoforum 58, 104-113. doi: 10.1016/j. geoforum.2014.10.015

Hess, M.; Yeung, H.W.-C. (2006): Whither Global Production Networks in Economic Geography? Past, Present, and Future. In: Environment and Planning A 38, 7, 1193-1204. doi: 10.1068/ a38463

Hitzler, R. (2011): Eventisierung. Wiesbaden.

Hitzler, R.; Kirchner, B.; Pahl, J. (2013): Event-Konzepte: Juvenile Inszenierungen zwischen Integration und Distinktion. In: Zeitschrift für Erziehungswissenschaft 16, 3, 143-158. doi: 10.1007/s11618-013-0429-6

Hoff, E.V.; Öberg, N.K. (2015): The role of the physical work environment for creative employees - a case study of digital artists. In: The International Journal of Human Resource Management 26, 14, 1889-1906. doi: 10.1080/09585192.2014.971842

Hofmann, M.L.; Vetter, A.K. (2014): Design Thinking. Das Denken, das Apple \& Co. groß gemacht hat. Paderborn.

Kelley, D.; Kelley, T. (2014): Kreativität und Selbstvertrauen. Der Schlüssel zu Ihrem Kreativbewusstsein. Mainz.

Klaaßen, L. (2017): Bürokonzepte: Die besten Ideen kommen vor dem Klo. In: Süddeutsche Zeitung vom 10. März 2017, 26.

Klein G. (2016): Marathon, Parade und Olympiade: Zur Festivalisierung und Eventisierung der postindustriellen Stadt. In: Sport und Gesellschaft 1, 3, 269-280. doi: 10.1515/sug2004-0307

Kroheck, V. (2013): Digitale Kreativitätstechniken im Rahmen des „Entrepreneurial Design Thinking“ unter Einsatz der e-Learning-Plattform „WebCT“. Masterarbeit im Studiengang Informationsmanagement, Universität Koblenz-Landau.

Lange, B.; Power, D.; Suwala, L. (2014): Geographies of fieldconfiguring events. In: Zeitschrift für Wirtschaftsgeographie 58, 4, 187-201. doi: 10.1515/zfw.2014.0013

Lee, Y.S. (2016): Creative workplace characteristics and innovative start-up companies. In: Facilities 34, 7/8, 413-432. doi: 10.1108/ F-06-2014-0054

Lewis, M.; Moultrie, J. (2005): The Organizational Innovation Laboratory. In: Creativity and Innovation Management 14, 1, 73-83.doi: 10.1111/j.1467-8691.2005.00327.x

Lindberg, T.; Gumienny, R.; Jobst, B.; Meinel, C. (2010): Is There a Need for a Design Thinking Process? In: Dorst, K.; Stewart, S.; Staudinger, I.; Paton, B.; Dong, A. (eds.): Proceedings of the $8^{\text {th }}$ Design Thinking Research Symposium. Sydney, 243-254.

Lindberg, T.; Noweski, C.; Meinel, C. (2010): Evolving discourses on design thinking: how design cognition inspires meta- 
disciplinary creative collaboration. In: Technoetic Arts 8, 1, 31-37. doi: 10.1386/tear.8.1.31/1

Lubart, T.I. (2001): Models of the Creative Process: Past, Present and Future. In: Creativity Research Journal 13, 3-4, 295-308. doi: 10.1207/S15326934CRJ1334 07

Luhmann, N. (2000): Vertrauen. Ein Mechanismus der Reduktion sozialer Komplexität. Stuttgart.

Magadley, W.; Birdi, K. (2009): Innovation Labs: An Examination into the Use of Physical Spaces to Enhance Organizational Creativity. In: Creativity and Innovation Management 18, 4, 315-325. doi: 10.1111/j.1467-8691.2009.00540.x

Martens, Y. (2011): Creative workplace: instrumental and symbolic support for creativity. In: Facilities 29, 1/2, 63-79. doi: 10.1108/02632771111101331

Maskell, P.; Bathelt, H.; Malmberg, A. (2006): Building global knowledge pipelines: The role of temporary clusters. In: European Planning Studies 14, 8, 997-1013. doi: 10.1080/09654310600852332

Mayring, P. (2010): Qualitative Inhaltsanalyse. Grundlagen und Technik. Weinheim/Basel.

McCoy, J.M. (2005): Linking the Physical Work Environment to Creative Context. In: The Journal of Creative Behavior 39, 3 , 167-189. doi: 10.1002/j.2162-6057.2005.tb01257.x

McCoy, J.M.; Evans, G.W. (2002): The Potential Role of the Physical Environment in Fostering Creativity. In: Creativity Research Journal 14, 3-4, 409-426. doi: 10.1207/S15326934CRJ1434_11

Meinel, C.; von Thienen, J. (2015): Design Thinking. In: Informatik Spektrum 39, 4, 310-314. doi: 10.1007/s00287-016-0977-2

Merkel, J. (2015): Coworking in the city. In: Ephemera 15, 2, 121-139.

Müller, M.; Stewart, A. (2016): Does Temporary Geographical Proximity Predict Learning? Knowledge Dynamics in the Olympic Games. In: Regional Studies 50, 3, 377-390. doi: 10.1080/00343404.2014.917168

Nonaka, I.; Toyama, R.; Nagata, A. (2000): A firm as a knowledgecreating entity: a new perspective on the theory of the firm. In: Industrial and Corporate Change 9, 1, 1-20. doi: 10.1093/ icc/9.1.1

Oksanen, K.; Ståhle, P. (2013): Physical environment as a source for innovation: investigating the attributes of innovative space. In: Journal of Knowledge Management 17, 6, 815-827. doi: 10.1108/JKM-04-2013-0136

o.V. (2010): Kreativräume: Komm Chef, gehen wir spielen! In: Die Presse vom 5. September 2010, 15.

Pallasmaa, J. (2014): Space, Place and Atmosphere. Emotion and Peripherical Perception in Architectural Experience. In: Lebenswelt 4, 230-245. doi: 10.13130/2240-9599/4202

Perlick, T. (2014): Forschungsfeld ,Eventisierte Hochschule: Vorüberlegungen zu einem Projekt. In: Hitzler, R.; Gothe, M. (eds.): Ethnographische Erkundungen. Methodische Aspekte aktueller Forschungsprojekte. Wiesbaden, 59-68. doi: 10.1007/978-3-658-07257-5

Perry-Smith, J.E.; Shalley, C.E. (2003): The Social Side of Creativity: A Static and Dynamic Social Network Perspective. In: The Academy of Management Review 28, 1, 89-106. doi: 10.2307/30040691

Plattner, H.; Meinel, C.; Leifer, L. (eds.) (2018): Design Thinking Research. Making Distinctions: Collaboration versus Cooperation. Cham. doi: 10.1007/978-3-319-60967-6

Robertsson, L.; Marjavaara, R. (2015): The Seasonal Buzz: Knowledge Transfer in a Temporary Setting. In:
Tourism Planning and Development 12, 3, 251-265. doi: 10.1080/21568316.2014.947437

Rutten, R. (2017): Beyond proximities. The socio-spatial dynamics of knowledge creation. In: Progress in Human Geography 41, 2, 159-177. doi: 10.1177/0309132516629003

Rutten, R. (2014): Learning in socio-spatial context: an individual perspective. In: Prometheus 32, 1, 67-74. doi: 10.1080/08109028.2014.945291

Rutten, R.; Boekema, F. (2012): From Learning Region to Learning in a Socio-spatial Context. In: Regional Studies 46, 8, 981-992. doi: 10.1080/00343404.2012.712679

Rychen, F.; Zimmermann, J.-B. (2008): Clusters in the Global Knowledge-based Economy: Knowledge Gatekeepers and Temporary Proximity. In: Regional Studies 42, 6, 767-776. doi: 10.1080/00343400802088300

Sauvonnet, E.; Blatt, M. (eds.) (2015): Wo ist das Problem? Design thinking als neues Management-Paradigma. Norderstedt.

Schmidt, S.; Brinks, V. (2017): Open creative labs: Spatial settings at the intersection of communities and organizations. In: Creativity and Innovation Management 26, 3, 291-299. doi: 10.1111/caim. 12220

Schumpeter, J. (2008): Konjunkturzyklen. Eine theoretische, historische und statistische Analyse des kapitalistischen Prozesses. Neuausgabe. Göttingen.

Schüßler, E.; Grabher, G.; Müller-Seitz, G. (2015): Field-Configuring Events: Arenas for Innovation and Learning? In: Industry and Innovation 22, 3, 165-172. doi: 10.1080/13662716.2015.1038098

Seitz, T. (2017): Design Thinking und der neue Geist des Kapitalismus: Soziologische Betrachtungen einer Innovationskultur. Bielefeld.

Shibata, S.; Suzuki, N. (2004): Effects of an indoor plant on creative task performance and mood. In: Scandinavian Journal of Psychology 45, 5, 373-381. doi: 10.1111/j.14679450.2004.00419.x

Sihvonen, T.; Cnossen, B. (2015): Not only a workplace. Reshaping creative work and urban space. In: Observatorio Journal 9, 47-69. https://doi.org/10.15847/obsOBS002015973

Smith, A. (2015): Events in the City. Using public spaces as event venues. London.

Spigel, B. (2017): The Relational Organization of Entrepreneurial Ecosystems. In: Entrepreneurship Theory and Practice 41, 1, 49-72. doi: 10.1111/etap.12167

Steidle, A.; Werth, L. (2013): Freedom from constraints: Darkness and dim illumination promote creativity. In: Journal of Environmental Psychology 35, 67-80. doi: 10.1016/j. jenvp.2013.05.003

Storper, M.; Venables, A.J. (2004): Buzz: face-to-face contact and the urban economy. In: Journal of Economic Geography 4, 4, 351-370. doi: 10.1093/jnlecg/lbh027

Suwala, L. (2014): Kreativität, Kultur und Raum. Ein wirtschaftsgeographischer Beitrag am Beispiel des kulturellen Kreativitätsprozesses. Wiesbaden. doi: 10.1007/978-3-65806581-2

Thoring, K.; Desmet, P.; Badke-Schaub, P. (2018): Creative environments for design education and practice: A typology of creative spaces. In: Design Studies 56, 54-83. doi: 10.1016/j. destud.2018.02.001

Toker, U.; Gray, D.O. (2008): Innovation spaces: Workspace planning and innovation in U.S. university research 
centers. In: Research Policy 37, 2, 309-329. doi: 10.1016/j. respol.2007.09.006

Torre, A.; Rallet, A. (2005): Proximity and Localization. In: Regional Studies 39, 1, 47-59. doi: 10.1080/0034340052000320842

Uebernickel, F.; Brenner, W.; Naef, T.; Pukall, B.; Schindlholzer, B. (2015): Design Thinking. Das Handbuch. Frankfurt am Main.

Vithayathawornwong, S.; Danko, S.; Tolbert, P. (2003): The Role of the Physical Environment in Supporting Organizational Creativity. In: Journal of Interior Design 29, 1-2, 1-16. doi: 10.1111/j.1939-1668.2003.tb00381.x

Wallas, G. (2014): The Art of Thought. First published in 1926. Tunbridge Wells.

Waseem, D.; Biggemann, S.; Garry, T. (2018): Value co-creation: The role of actor competence. In: Industrial Marketing Management 70, 5-12. doi: 10.1016/j.indmarman.2017.07.005

Weber, H.; Rodriguez, A.C.; Mateus, A. (2016): Innovation gestalten. Design Thinking als Schlüssel in die Zukunft. In: SEMRADAR. Zeitschrift für Systemdenken und Entscheidungsfindung im Management 15, 2, 75-93.

Willenbrock, H. (2014): Die stille Botschaft der Räume. In: Brand Eins 4, 74-81.

Zhu, H.; Chen, K.; Lian, Y. (2018): Do Temporary Creative Clusters Promote Innovation in an Emerging Economy? A Case Study of the Beijing Design Week. In: Sustainability 10, 767, 1-21. doi: $10.3390 /$ su10030767 